\title{
Impact on the Workers on the Closure of the Jute Mills in Bangladesh
}

By

\author{
Professor Dr. Md. Kayemuddin
}

\begin{abstract}
The paper examines the impact on workers of the closed jute mills and other Mills. The study is based upon field survey of 200 workers of 56 closed down mills by the order of Government. About 55,000 workers became affected for the closure of the mills. Reactions and experiences of the affected workers are collected, processed and furnished in this study. The role that various agencies played and should have been played to help the affected workers in the process of rehabilitation are discussed here. Based on the findings of the study recommendations are made to provide relief and financial help to the affected workers and also who may be affected by such closure of the mills in the future.
\end{abstract}

Keywords: Jute Mills, environment, workers, income.

\section{Introduction}

Rapid industrialization is the policy of the government for the quick development of the country. Bangladesh is still not, an industrial country. At the initial stage of the independence of the country had a few industrial units. Without considering any repercussion of the nationalization of the industry the mills were nationalized by the government. The problems they may face in the long run were not taken into consideration. As a result, a few years after the nationalization, it was found that the mills incurred a huge amount of net loss due to mismanagement and uncontrolled, unproductive and unplanned expenditures. Subsequently, the government closed the mills. Because of the closure of the mills the workers faced many problems in the form of economic hardship, mental stress and mental disorderliness. Concerned as a civilized society. Governments, environmentalists and the three actors (i.e. management, union and Government) of industrial relations system were aware about the sufferings of the affected workers and as such it called for efficient management of the mills and factories

\section{Background}

In view of the large scale closure of the jute mills. Misery of the affected workers knew no bound .It was decided to take a research study to look into the process of rehabilitation of workers affected by the closure of the industrial units in Bangladesh as a 
result of government decision. The study is expected to help in understanding the consequences of closure in terms of its effects on workers and their families. Based on this knowledge, long-term strategies can be chalked out to handle with such a situation. It also helps in identifying the role that trade unions can play in helping the affected workers in the process of rehabilitation. Thus, the present study tries to ascertain the affected workers reactions to the govt. decision and the roles, if any, that various agencies should play in future to deal with such situations so as to minimize the sufferings and miseries of the affected workers.

Regulatory framework for the affected workers of the closed mills.

Though there is rules and regulations to protect the rights of the affected workers regard less of whether the owners of the affected units chose to relocate the units or not. The government was also requested to help the units in the process of relocation. The workmen employed in these closed industries were entitled to the rights and benefits indicated below:

a) The workers shall have continuity of employment in the new units if the industry is shifted. The terms and conditions of their employment shall not be changed;

b) The workers shall be in active service during the period of setting up of new units and up-to the time. The closed units are started again. The affected workers shall be given full wages with service continuity.

c) The affected workers shall be given one year's wages as shifting bonus to help them settle at the new location or for their self employment.

The affected workers who do not want to work in the relocated units shall be considered as retrenched workers from the date of closure of the mills if they work at one year in the closed units, they shall be paid compensation as per Industrial Disputes Act.

d) The workmen employed in the industries which fail to relocate themselves and the workmen who are not willing to shift along with the relocated industries shall be deemed to have been retrenched with effect from the closure of the mills, provided they have been in continuous service for not less than one year in the industries concerned before the closure of the mills. the said date. They shall be paid compensation in terms of these workmen shall also be paid, in addition, one year's wages as additional rules for compensation.

e) The "shifting bonus" and the compensation payable to the workmen in terms of this judgment shall be paid by the management before the closing down of the mill.

As per the government order, the affected workers of the closedown mills shall be paid before the mills are finally closed down.

Though the government had given certain directives, the question is whether these instructions are followed fully or not. Closure affects workers not only economically but also psychologically and physically such decisions are likely to change the life-style of the workers and their families. The important issue is rehabilitation of these workers who are the main sufferers in the whole process.

\section{Objectives of the Study}

1) To examine the experiences of workers rendered surplus as a result of closure of industrial units. 
2) To find out whether the workers have been paid compensation due to them and to look into the ways in which they have utilized the same.

3) To assess the impact of closure of the mills on the affected workers.

4) To examine the role of different agencies, including trade unions, in helping the workers to cope with their situation in the process of rehabilitation.

5) To gain experience of the payment procedures and other concerned matter in settling the whole thing of closer of the mills.

6) To acquire knowledge of closure of the mills and settlement procedures of the receivables of the affected workers.

\section{Methodology}

About 72 Jute Mills and 74 Textile mills were closed by the government. Convenience method of sampling was adopted for this study. As and when the affected workers were available, then data were collected from them. Data relating to these workers were collected through interviews with the help of a structured questionnaire designed specifically for the study. Moreover, group discussions with the affected workers were also held and discussions and interviews with the management were also held. The Union leaders were also discussed.

A Training Program was organized by a NGO for the skill development of the affected workers. More than 200 workers of the closed mills who attended the training programme for their skill development were interviewed for the collection of information and data. Respondent were of the homogenous group and as such 200 respondents were considered sufficient for this purpose.

\section{Findings}

\section{a) Profile of workers}

A majority of such affected workers (more than 60 per cent) belonged to the age group of 25-45 years, mean age of the sample being 35 years. In all 90 per cent of the respondents were Muslims whereas 5 per cent were Hindu. Only 5 per cent of the respondents belonged to the other religions. A majority of the respondents (65 per cent) were from low income group and 35 per cent were from middle class families. . Very small portion of them were from North Bengal \& South Western part of Bangladesh. Most of these workers were from Noakhali and Comilla (eastern part of Bangladesh). For their livelihood they had been working in these industries/factories for the past several years. A majority of them (86 per cent) belonged to nuclear families and who were the main earning member of the families. Only 7 per cent were reported to be staying in joint families, while another 7 per cent were either unmarried or were staying alone in the mill area.

b) Re-action of workers in the first instant

Reaction of Workers towards Closure of the mills Some of the workers became fainted after hearing the news of closure of the mills. Some of the members of the families of the affected workers got terribly shocked at the news of the closure of the mills. 


\section{Instant Reaction of the workers}

When the workers got the information of closure of the mills some of the workers at least 20 percent fainted and some one at least 10 percent got heart attack. Most of the workers about 70 percent became agitated and suffered from mental agony. In the next time they realized that all of them would be soon unemployed and they imagine that their income would fall drastically and with the income level goes down, the standard of living also went down and life style would change. Education of the female children of the affected workers were stopped and thereafter the education of the female members of the family were stopped. Children refrained from going to the school.

\section{Other Impact on Workers of Closure of the mills:}

The researchers conducted several studies on the impact on the workers families. These studies reveal impact on medical treatment, education, relationship, food intake, mental imbalance, increase in poverty level after becoming unemployed due to closure of the mills.

\section{Income and. Economic Status}

In a majority of cases (82 per cent), the workers reported that their income had gone down and they became poorer, which is quite natural in such circumstances. They would not get their usual wages or the compensation due to them. In many cases, where a decision was still pending in the court, Petition after petition and appeal after appeal did not helped the workers in getting their legitimate dues in time. Due to lack of money , most of them(85percent) could not repair their dwelling houses and as such in the heavy rain fall their beds and goods got wet some of them(40 percent) sold their land and other house hold items for the repairing of their houses.

\section{Medical Treatment:}

There were changes in the pattern of medical treatment of the respondents and their families. Almost 70 per cent stated that there was a change in medical facilities available to them due to the closure of the mills; while almost one-third of them said that earlier they were not getting any medical facilities/benefits. Majority (75 percent) were either going to government hospitals or consulting private doctors in case of illness. Almost one-third of the workers stated that due to closure, they were deprived of ESI facility, while another one-third said that they were now going to government hospitals as it was free but the treatment was not good and at times they had to buy costly medicines from the market. Whereas 10 per cent of workers had shifted to homeopathy for treatment as it was cheaper, another 20 percent stated that for minor treatment they still preferred to consult nearby private doctors. Earlier, some workers were getting medical allowances, or if something happened while working, owners used to take care of them. Altogether, 10 per cent of the respondents remarked that now they had to spend their personal money, while some others stated that they tried to bear the pain and that only in emergencies they visited government hospitals.

\section{Impact of food intake.}

Regarding the per capita intake of food per day, it came down from the national average dose of 863 grams. 
Regarding, per capita intake of protein, it came down from the recommended dose of 48 grams per person per day. As a constant downfall of the protein intake the children were suffering from malnutrition and as a result of constant malnutrition other diseases broke out in the families of affected workers.

Health condition of the members of the affected workers' families deteriorated as they cannot take nutrient food properly, as the income level was gone down. Most of them compelled to change their food habit. Social position downgraded as they became unemployed. As the income level of the affected workers went down the members of the affected families had clothing problem. Most of the affected families could not buy clothes for wearing. They had to wear one set instead of two or three sets of cloth and could not clean the cloth as they did in the past. They had to wear dirty cloth and they exposed to shabby looking appearance

The affected families cannot provide milk, fish and meat to the children and other members of the family as a result, children and others suffers from malnutrition. Most of the affected workers had to bear the family maintenance expenses from their savings and loan from relatives. Savings also depleted and no money was available for further spending for the family needs. Details sufferings are given below:

When asked if there had been any change in their food habits or those of their family members, almost 75 per cent of the sample workers reported that there had been a change, whereas 25 per cent reported That there was no change. Further the 40 per cent of the respondents were consuming poorer quality of food, as they were buying cheaper quality of rice, wheat and vegetables 15 per cent stated that they used to visit market when it was about to close, as at that time they could buy vegetables at lower price. Onefifth of them (40 per cent) reported that they had curtailed expenses on food items. As they took meals only in one time. About 20 per cent mentioned that earlier they used to consume non-vegetarian food quite frequently, but now they have either totally stopped eating non-vegetarian items or consume it only once in a week. Others reported that they have no food problem. The news of unconditional closure of the units by government. in 1996 came as a shock to a majority of the respondents ( 85 percent). While some workers did nothing and just waited for final process of closure of the mills, others approached the managements for more specific information and to learn about their current status and future situation in the organization. Some workers approached trade union leaders for guidance and help. 66 per cent of sample affected workers disclosed the information on the same day to their family members. But only 33 percent of the sample respondents did not want to disturb their families immediately and adopted the wait and watch policy. In most cases the families felt quite upset on hearing the news and considered their future is very dark and uncertain. Union leaders advised affected workers to meet the management for solution others asked them to search for alternative jobs. Some families of the affected workers got terribly shocked at the news of the closure of the mills.

\section{Other Impact}

\subsection{Impact of Closure}

The researchers conducted several studies on the impact on the workers families. These studies reveals impact on medical treatment, education, relationship, food intake, mental 
imbalancement, increase in poverty level after the unemployment due to closure of the mills.

Health condition of the members of the affected workers deteriorated as they cannot take food properly, such as milk, fish, meat and nutrias food as the income level was gone down. Most of them compelled to change their food habit. Social position downgraded as they became unemployed. As the income level of the affected workers gone down the members of the affected families had to wear one set of cloth instead of two or three sets and cannot clean the cloth as they did in the past.

The affected families cannot provide milk to the children, as a result, children suffers from malnutrition. Most of the affected workers had to bear the family maintenance expenses from their savings. Savings also depleted and no investment was available for further spending for the family needs. Details sufferings are given below:

The news of unconditional closure of the units by the govt. 1996 came as a shock to a majority of the respondents. While some workers did nothing and just waited for final process of closure of the mills. others approached the managements for more specific information and to learn about their current status and future situation in the organization. Some workers approached trade union leaders for guidance and help. Two thirds of affected workers disclosed the information on the same day to their family members. But only one third did not want to disturb their families immediately and adopted the wait and watch policy. In most cases the families felt quite upset on hearing the news and considered their future is very dark. Some of them advised the affected workers to approach to the management for some solution, while others asked them to search for alternative jobs.

Some of the workers became fainted after hearing the news of closure of the mills. Some families of the affected workers got terribly shocked at the news of the closure of the mills

\subsection{Medical Treatment:}

There were changes in the pattern of medical treatment of the respondents and their families. Almost 70 per cent stated that there was a change in medical facilities available to them due to the closure of the mills, while almost one-third of them said that earlier too they were not getting any medical facilities/benefits. Majority were either going to government hospitals or consulting private doctors in case of illness. Almost one-third of the workers stated that due to closure, they were deprived of ESI facility, while another one-third said that they were now going to government hospitals as it was free but the treatment mended was not good and at times they had to buy costly medicines from the market. Whereas 10 per cent of workers had shifted to homeopathy for treatment as it was cheaper, another 7 per cent stated that for minor treatment they still preferred to consult nearby private doctors. Earlier, some workers were getting medical allowances, or if something happened while working, owners used to take care of them. Altogether, 6 per cent of the respondents remarked that now they had to spend their personal money, while others stated that they tried to bear the pain and that only in emergencies they visited government hospitals.

\section{Compensation}


It took some time to process the compensation. The exact situation is not clear as yet the management paid in time, the benefits for one reason or another, or even extended the needed help to workers to solve their problems. In some cases, where genuine efforts were made to locate the workers, the management could not do so, as they had been away from the factory and were also not available at their permanent/local addresses. This also caused delay in the payment of Provident Fund amount, etc. to the affected workers. Even where alternative jobs were arranged, it did not fetch sufficient income. Only 13 per cent of the respondents reported that there was no change in their monetary status, as their company was paying regular salaries to them. about 3.7 per cent of the sample respondents having new job, they got higher salary. Respondents felt that their income had increased after closure, as they had been able to find similar jobs but with better income. Taking loans is not something unusual among the workers. But if we consider the reasons for taking loans before and after closure, we got an idea about the financial status of the workers affected by the government order for closure of the mills.

In the past, the dominant reasons for taking loans included:

(a) Marriage of a daughter/sister or education of children (46.67 per cent), and

(b) Purchase of food, repairing of house and repayment of old loans ( 30 per cent).

(c) Other reasons of taking loan were to pay medical expenses.

On the other hand, the single most important reason for taking loans after closure was meeting day-to-day expenses for running the household (70 per cent). When they were in service, no one was reported to have taken a loan for this purpose. The additional reasons for taking loans after the closure of mills was the undertaking of projects for income generating activities.

\subsection{Self Employment Programme}

(a) To generate self-employment through undertaking income generating activities, In the line of grameen bank, Income Generating Activities were undertaken by the sample affected workers. Activities like, cow fattening, plumbing, masonry, items of cottage industries, etc., and for these activities training were given by the NGOs for their skill development so as to enable them to undertake those activities. About 500 affected workers trained in these training programmes. After training the trained workers were attached to the banks for micro credit.

\subsection{Education}

When asked about the change in the pattern of education of their children, nearly 25 percent of the respondents said that their children stopped going to schools because of financial crisis, while 12 per cent mention to private schools but now they are going to government schools where the standard of education is low. Earlier some of the children were going for private tuitions, now they have stopped going to the private tutors tuitions, which in turn affected their performance at school. Some workers mentioned that their children had failed in the examination because of change in school and/or lack of engaging private for tutor. Another 30 per cent respondents reported that due to financial crisis, their children had stopped going to school and had started working in factories or private jobs. In order to support the schooling of one child, the other 
(preferably female child) had been taken off from the school. One striking finding was that the education off boys was given priority and, therefore, education of the girl child was being totally stopped. Parents were finding it very difficult to meet the schooling requirements of their children. 80 percent of the workers felt helpless due to closure of the units. They were ashamed of their status of being jobless persons, which had made them frustrated and depressed. In some cases (10 per cent) this helplessness was so severe that they did not feel like living and felt like committing suicide. If they did not do so, it was because of realization of their family responsibilities. After sitting at home, the sample respondents felt that their working capacity had deteriorated.

\subsection{Status of Workers}

Man is a social animal. The changed employment status had repercussion on the existing relationships of the workers, both within and outside their families. They did not enjoy the same status within the family as they did earlier and this has created a feeling of anxiety and psychological disorders among them. They felt that their present status of non-earners had gradually made them losing control over family affairs. About onefourth of the respondents reported having experienced no change in relationships within the family, while 20 per cent felt that their inability to fulfill the family needs had made them sad. The family atmosphere was not cordial and the members were not as happy as they were earlier. Gradually, family members were losing faith in them. As a result, they had developed a feeling of inferiority: a sense of anxiety, tension and irritableness. A few others felt that they were unable to send any money home, which, in turn, had generated lot of misunderstandings among them and of the family members. On the other hand, 11 per cent respondents considered themselves fortunate, as their family members try to boost their morale, and encourage them. Despite all tensions and agonies, some people found supporting relationships within the family. Considering the relationship outside the family, 25 percent of the respondents stated no change in relationships with friends, neighbors and society at large. 30 per cent respondents felt that people did not show respect for them and now try to take undue advantage of the situation. Due to their new "unemployment" status, shopkeepers and others (particularly money lenders) stopped lending money. Friends and relatives did not interact with them under the apprehension that they would ask for money. Workers themselves avoided interacting with them and stopped going to social functions. Some respondents sent their families to their native place, but in the village also conditions were no better, as head of the family was not earning.

\section{Rehabilitation of workers}

\subsection{The Closed Units}

As per government order, workers employed in industrial units that fail to relocate themselves at sites outside the prohibited areas of Dhaka are required to be paid compensation equivalent to their 6 years' wages. Such units are deemed to have closed down permanently. In our sample of 200 workers, 47 workers belonged to such closeddown units. It is significant to note that almost half of the workers (51 per cent) had not received any compensation till the time of this study. Only 23 of these workers (49 per cent) are reported to have received some compensation. Surprisingly, full compensation 
(equivalent to 6 years wages) is reported to have been paid to only five workers (10.64 per cent). Table 4 gives details about payment of compensation to workers belonging to the dosed units.

Reasons vary for these six types of payment of compensations to workers of the closed units. Majority fall in the category where no compensation of any kind has been paid. Lack of adequate knowledge, support and timely action on the part of the workers has contributed to this situation. Some were lucky to have considerate employers. They could get some lump sum amount. Break-up of that sum was not given to them even when they asked for it. Quietly the workers accepted whatever amount came to them. Very few workers got compensation equivalent to six year's wages. Since the amount to be paid was not much for the management they could make full payment to such affected workers and close down their units.

Some other gainful business was started by them but no old employee was offered any job in the new business by the old employer. Some reported to have faced great difficulty in getting their provident fund money. But at least 6.38 per cent could get that.

Workers belonging to this category are reported to have been utilizing their compensation money mostly for meeting their day-to-day family requirements. Some of these workers invested part of the money in a bank for use in the future, while some others used it for generating self-employment.

\subsection{Role of the agencies in the rehabilitation process:}

Payment of compensation to the workers is the most pressing first step in the direction of rehabilitation of the workers affected by closure of their units. That most of them have not been able to receive the monetary compensation due to them as per the norms prescribed by the government order is a poor reflection on the administrative machinery of the government that is required to oversee implementation of the government order. The trade unions must also pay a more active role in persuading the managements to release the money due to the workers. Last but not the least, the employers of the affected 146 units must, as a very minimum, honor their legal obligations insofar as payment of compensation is concerned.

But monetary compensation is just one (though an important one) of the requirements of proper rehabilitation of the affected workers. Many of the displaced workers need help and guidance in more ways than one. They need advice regarding proper investment of their compensation money as also in their search for alternative means of livelihood or job hunt. In some cases, the workers may require new skills for which training facilities need to be identified or created. They also need help to ensure that their children can continue their schooling. Last but not the least, if some workers are rendered homeless, they need help in finding suitable alternative accommodation.

International Agencies, donors may come forward to provide them with financial assistance so that they can overcome such situation of socio-economic turmoil. Rehabilitation of displaced workers involves multiple steps to be taken by a number of agencies. Any well-planned strategy, therefore, all for an integrated approach instead of leaving the task to a number of agencies, each acting on a piece-meal basis. An integrated approach, in turn, requires coordination of the activities of different agencies. The responsibility for coordination of a planned rehabilitation programme will have to be 
shouldered by the government. More studies are needed for the solution of this great problem.

\section{Recommendation:}

The following recommendations have been offered to help solving and tackling the situation arises due to the closure of the mills.

1. On the closure of any mills, the management of the mills should publish, a list of the affected workers with the amount due to them against their names.

2. The management is to arrange their payments quickly and without any delay.

3. The donors and International agencies are requested to come forward to help the rehabilitation of the affected workers.

4. The trade union should help the affected workers in getting their receivables as early as possible.

\section{Conclusion:}

1. Donors, International Agencies and govt. should come forward to help the affected workers in their rehabilitation process.

2. Trade union should involved themselves with management of the closed units in setting the problems of the affected workers.

3. The affected workers were mostly 85 percent were lower middle class people but because of the closure of the mills. They (affected workers pushed into below subsistence level. This article has been written to give an idea of the impact of closure of the mills and problems of settlement process and requirements of help especially financial help and other help for full settlement of the cases arise due to closure of the mills.

\section{Reference}

Lahiri, S., “ Fighting For a Basque Framework of Labour Relations”, Labour File, Vol.6, No.5, May 2000,pp.17-18.

Mishra, Prashant \& Dhar, Upinder, “ Labour Management Partnership : An Indian Perspective”, Indian Journal of Industrial Relations, Vol.36, No.1, July 2000,pp.92-97.

Tuselmann, Heinz \& Heise Arne," The German Model of Industrial Relations at the Cross Roads: Past, Present and Future", Industrial Relations Journal : European Journal of Analysis, Policy and Practice, Vol.31, No.3, September 2000,pp.162-176.

Agarwala, S. L., Labour Relations Law in India, Meerut, Macmillan, 1978.

Allen, D., Fringe Benefits: Wages of Social Obligation: An Analysis with Historical Perspectives from Paid Vacations, New York, Cornell University, 1969.

H.M.S.O., Industrial Relations Handbook.

Barrie, o.p., Labour turnover and Retention, Gower Press, 1975.

Beveridge, W., "Social Insurance and Allied Services", Report Presented to Parliament by Command of his Majesty, London, HMSO 1942 as quoted in Vaid, K.N., Labour Welfare in India, New Delhi, Shri Ram Centre for Industrial Relations, 1970.

Chopra, D.S., Outline of Labour Law, Bombay, N.M. Tripathi (P.) Ltd., 1974.

Dhyani, S.N., ILO and India, In Pursuit of Social Justice, New Delhi, National Publishing House, 1977.

Venkatachalam, S., Pillai Committee Report on Compensation System of 14 Nationalized Bank Officers, Bombay, Industrial Relations Institute of India, 1978. 